\title{
Congenital haemolytic anaemia resulting from glucose phosphate isomerase deficiency: genetics, clinical picture, and prenatal diagnosis
}

\author{
A. G. L. WhitelaW, P. A. ROGERS, D. A. HOPKINSON, H. GORDON, \\ P. M. EMERSON, J. H. DARLEY, C. REID, AND M. d'A. CRAWFURD \\ From the Departments of Paediatrics, Obstetrics, and Haematology, Northwick Park Hospital; the \\ Division of Inherited Metabolic Disease, Clinical Research Centre, Northwick Park Hospital; \\ the MRC Human Biochemical Genetics Unit, The Galton Laboratory, University College London; and \\ the Department of Haematology, Radcliffe Infirmary, Oxford.
}

SUMMARY Glucose phosphate isomerase (GPI) deficiency with severe haemolysis and hydrops fetalis was found in the first child of unrelated, healthy Caucasian parents. The child died at 3 hours. Both parents were found to have $50 \%$ of normal red cell GPI activity and qualitative tests on their red cells and white cells showed that each was heterozygous for a different GPI variant allele associated with enzyme deficiency. Tests on the placenta showed that the propositus was a 'compound' heterozygote.

Examination of amniotic cells obtained by amniocentesis on the mother at 28 weeks in her second pregnancy led to the prenatal diagnosis of GPI deficiency. This second child, a 'compound' heterozygote at the GPI locus indistinguishable from the first, was successfully treated by immediate exchange transfusion and subsequent blood transfusions.

Glucose phosphate isomerase (EC: 5.3.1.9) (GPI) is a dimeric enzyme which catalyses the interconversion of fructose-6-phosphate and glucose-6-phosphate. It is determined by an autosomal locus which has been assigned to chromosome 19 (McMorris et al., 1973). Several electrophoretic variants have been identified in population studies on normal healthy subjects in addition to the common phenotype GPI 1 (Detter et al., 1968; Shinoda, 1970; Tariverdian et al., 1970; Welch, 1971; Omoto and Blake, 1972). The variant alleles are mostly rare with the exception of $G P I^{3}$ which reaches polymorphic frequency in some Indian populations (Blake et al., 1971).

Some electrophoretic variants are associated with deficient activity of GPI and may manifest with nonspherocytic haemolytic anaemia. The affected subjects may be homozygous for the variant allele causing GPI deficiency, for example, GPI Espeln, also known as phenotype GPI 9 (Arnold et al., 1973). In other cases, patients have been shown to be heterozygous for two different variant alleles both associated with GPI deficiency, for example, GPI Seattle, also known as phenotype GPI 9-10 (Baughan et al., 1968; Detter et al., 1968). In some other cases, Received for publication 30 August 1978 the product of the variant allele is indistinguishable electrophoretically from normal, and indeed sometimes the alleles appear to be 'silent'.

The various reports of GPI deficiency associated with haemolytic anaemia were reviewed by Paglia and Valentine (1974). Several new cases have been identified since then; for example, GPI Utrecht (van Biervleit, 1975), GPI Nordhorn (Schröter et al., 1974), and GPI Barcelona (Kahn et al., 1977), and the genetic and molecular basis for haemolysis because of GPI deficiency has been reviewed recently (Kahn et al., 1976, 1977; Schröter and Tillmann, 1977). Most of the cases are relatively mild, but there is a report of a family from Kentucky in which 3 of 4 affected children in a family of 8 died, one at the age of 11 days (Hutton and Chilcote, 1974).

A family is described here in which 2 sibs have had severe congenital non-spherocytic haemolytic anaemia because of deficient activity of GPI. The first child died at 3 hours with hydrops fetalis. The second child was diagnosed antenatally by amniocentesis at 28 weeks' gestation, and was successfully treated by exchange transfusion following delivery at 35 weeks and subsequent blood transfusions. Each 
parent was found to be heterozygous for a GPI variant allele associated with enzyme deficiency. Both children were heterozygous for the two different parental variant alleles. This family is of particular interest in view of the severity of the haemolytic disorder and the successful antenatal diagnosis of GPI deficiency.

\section{Materials and methods}

\section{PREPARATION OF SAMPLES}

Red cells. Whole blood, collected into lithium heparin, was centrifuged at $2000 \mathrm{~g}$ for 10 minutes and the plasma and white cells removed. Red cells were washed three times in cold $0.9 \%$ saline and stored as packed cells in liquid nitrogen.

White cells. $1 \mathrm{ml}$ distilled water was added to the white cell pellet to lyse contaminating red cells and the tube was left to stand for 1 minute; $10 \mathrm{ml} 0.9 \%$ saline was added and the mixture spun at $2000 \mathrm{~g}$ for 5 minutes. The supernatant was removed and the above process repeated twice. White cell pellets were stored in liquid nitrogen until required.

Placental extracts. 1:1 w/v homogenates were prepared in distilled water, and cell debris was removed by centrifugation at $15000 \mathrm{~g}$ for 20 minutes.

Amniotic cells. The cells were cultured in Eagle's MEM with $10 \%$ fetal calf serum. After harvesting, cell pellets were stored in liquid nitrogen.

For enzyme assays haemolysates were lysed by dilutions of approximately 1 in 20 with distilled water. White cells and amniotic cells were sonicated in 1 to 2 drops of distilled water. Before assay, placental extracts and sonicates of white cells and amniotic cells were diluted (about $1: 4$ ) with $0 \cdot 1 \mathrm{M}$

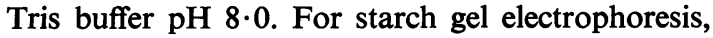
the samples were lysed by freeze-thawing and used without dilution.

Assays. The method for GPI was based on the procedure described by Chapman et al. (1962). 2,3diphosphoglycerate was determined according to the method of Keitt (1971). Other red cell enzymes and glycolytic intermediates were assayed according to methods recommended by the International Committee for Standardisation in Haematology (Beutler et al., 1977).

Starch gel electrophoresis. Horizontal starch gel electrophoresis of GPI was carried out for 18 hours at $4^{\circ} \mathrm{C}$. Two buffer systems were used. (1) Bridge buffer $0.3 \mathrm{M}$ Tris adjusted to $\mathrm{pH} 8.6$ with $\mathrm{HCl}$; gel buffer 1:15 dilution of the bridge buffer. The potential was set at $5.5 \mathrm{v}$ per cm and the current at $35 \mathrm{~mA}$. (2) Bridge buffer $0.5 \mathrm{M}$ Tris and $0.057 \mathrm{M}$ citric acid. This was made by adjusting the $\mathrm{pH}$ of a $0.057 \mathrm{M}$ citric acid solution to $\mathrm{pH} 8.6$ with a $2 \mathrm{M}$
Tris solution. The gel buffer was a 1:25 dilution of the bridge buffer. The potential was $6.0 \mathrm{v}$ per crif and the current 35 to $40 \mathrm{~mA}$.

The stain for GPI was applied as an agar overlay In a total volume of $40 \mathrm{ml}$ the mixture contained $0.5 \mathrm{M}$ Tris $\mathrm{pH} 8.0,3.0 \times 10^{-3} \mathrm{M}$ F-6-P, $7.5 \mathrm{~m}$. NADP, $7 \cdot 0$ units G6PD, $7 \cdot 5 \mathrm{mg} \mathrm{MTT}$, and $5 \mathrm{mg}$ PMS.

\section{HEAT STABILITY STUDIES}

Heating of gels. The method described by McAlpin $\overrightarrow{\overrightarrow{\mathrm{e}}}$ et al. (1970) was used at a temperature of $50^{\circ} \mathrm{C}$.

Heating of samples. Samples were heated in a wates bath at $45^{\circ} \mathrm{C}$ for periods of from 20 to 60 minutes? Immediately after heating, samples were plunge into ice for 10 minutes. They were then centrifuge at $15000 \mathrm{~g}$ for 15 minutes and the supernatants wer⿸\zh14口 assayed for GPI activity.

\section{Case report: case 1}

\section{CLINICAL FEATURES}

This baby (III.1, Fig. 1) was the first child of unrelated, healthy Caucasian parents. The mother (II.2) was aged 35 and the father (II.1) 34 at the time of delivery. The mother had had iron deficiencig anaemia 8 to 9 years previously and jaundice at the age of 10 or 11. During pregnancy she worked as dental nurse. She was mildly hypertensive in the las\% trimester, but had no other illnesses. During labourg which commenced at 35 weeks, there were period of fetal tachycardia and bradycardia. Delivery waฐ by forceps. The baby was female and had a birth?

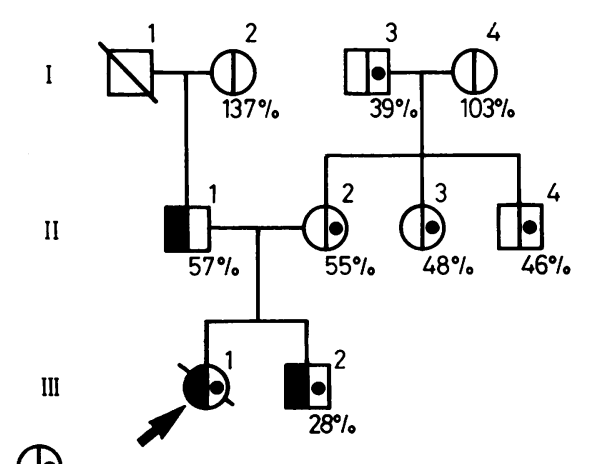

Reduced levels of GPI activity within the
heterozygote range
GPI deficiency with congenital haemolytic
anaemia

Fig. 1 Family study of GPI activity of red cells. The children have inherited both parental variant alleles; the maternal and paternal variant alleles are distinguishable by electrophoretic and other qualitative tests. 
weight of $2.54 \mathrm{~kg}$. She was pale, oedematous, slightly jaundiced, and was found to have massive enlargement of her liver and spleen. The clinical appearance was that of hydrops fetalis. At 1 minute she had an Apgar score of 1, a heart rate of $30 / \mathrm{min}$, and was apnoeic. She was intubated and intermittent positive pressure ventilation led to an increase in the heart rate, and the baby was breathing spontaneously by 5 minutes. After 15 minutes she had a cardiorespiratory arrest. She was given cardiac massage, further ventilation, and exchange transfusion was started. After $55 \mathrm{ml}$ had been exchanged she had two further cardiac arrests and died 3 hours after birth. Necropsy showed no abnormalities apart from dilation and thickening of the heart and hepatosplenomegaly.

\section{INVESTIGATIONS}

Cord blood: group A Rhesus negative; haemoglobin $4.7 \mathrm{~g} / \mathrm{dl}$; white cell count $75 \times 10^{9} / 1$; normoblasts $60 / 100$ wbc; platelets $60 \times 10^{9} / 1$; film: gross erythroblastosis and polychromasia, numerous red cell fragments and some spherocytes; direct antiglobulin test negative; plasma methaemalbumin and bilirubin raised; starch gel electrophoresis: normal amounts $\mathrm{Hb} \mathrm{A}$ and F; brilliant cresyl blue stain for $\mathrm{Hb} \mathrm{H}$ negative; red cell G6PD and pyruvate kinase (PK) activities normal.

Urine: organic acid content (in $\mu \mathrm{g} / \mu \mathrm{g}$ creatine) by gas chromatography and mass spectroscopy: raised levels lactic acid $(21 \cdot 1)$, pyruvic acid $(0 \cdot 3)$, 3-hydroxybutyric acid $(0 \cdot 7)$, and malic acid $(0 \cdot 7)$.

Maternal blood: group $\mathrm{O}$ Rhesus positive; Kleihauer test negative; no anti-A haemolysins or atypical antibodies. There was no abnormality in maternal or paternal red cell indices or morphology, and the isopropanol test for unstable haemoglobins was negative. Normal amounts of $\mathrm{Hb} \mathrm{A}$ and $\mathrm{A}_{2}$ were shown by electrophoresis, and G6PD and PK activities were normal in both parents. Heinz body stress tests were also normal.

\section{RESULTS OF ENZYME ST UDIES}

The clinical picture suggested a congenital red cell defect as the cause of haemolytic anaemia. However, the obvious common causes were excluded by the investigations on the cord blood and the parental blood samples. As the parents wished to have children and wanted to have further advice, red cells from both of them were sent to one of the authors (PE) for assay of other enzymes of the glycolytic pathway. The results of these studies showed that both parents had about half the normal level of red cell GPI activity, whereas the activities of the other enzymes tested, and the levels of various glycolytic intermediates including 2, 3 DPG, were normal.
A detailed investigation of the properties and activity of GPI in the parents and the first baby was then carried out using red cells and white cells from the parents and the placenta, which had been stored deep frozen since the delivery. These results are summarised in Table 1. It was confirmed that the parents had about half the normal red cell GPI activity; the placenta had only a quarter of the activity of a control placenta. The father's white cells showed reduced GPI activity compared to the control, but the heat stability of the enzyme in the father's white cells was similar to the control. In contrast, the GPI in the mother's white cells and the placenta was thermolabile compared with the enzyme in appropriate controls. The full heat inactivation profiles are shown in Fig. 2. Michaelis constants and $\mathrm{pH}$ optima of the GPI in crude white cell extracts from both parents were within normal range, and so was the $K_{m}$ F6P for the placental GPI.

On starch gel electrophoresis (Fig. 3a) and isoelectric focusing, the red cell GPI from both parents was indistinguishable from the common isozyme pattern, phenotype GPI 1 . The white cell extracts from the father also showed the common GPI 1 isozyme pattern. However, in the mother's white cells a variant component was seen in addition to the usual isozyme. This variant isozyme was more cathodal than the normal isozyme in the Tris/ chloride $\mathrm{pH} 8.6$ buffer system, but less cathodal in the Tris/citrate $\mathrm{pH} 8.6$ buffer system. Furthermore, the variant isozyme from the mother's white cells was unstable to heating at $50^{\circ}$, in contrast to the GPI 1 isozyme in the white cells of the mother, the father, and the control (Fig. 3b).

Table 1 GPI activity and properties from parents and placenta of case 1

\begin{tabular}{|c|c|c|c|c|}
\hline & $\begin{array}{l}\text { Father } \\
(I I . I)\end{array}$ & $\begin{array}{l}\text { Mother } \\
(I I .2)\end{array}$ & $\begin{array}{l}\text { Case I } \\
(I I I .1)\end{array}$ & Controls \\
\hline \multicolumn{5}{|l|}{ GPI activity } \\
\hline \multicolumn{5}{|l|}{ Red blood cells } \\
\hline $\begin{array}{l}\text { GPI IU/g Hb } \\
\text { GPI/LDH }\end{array}$ & $\begin{array}{r}11 \cdot 6 \\
7 \cdot 1\end{array}$ & $\begin{array}{l}9 \cdot 5 \\
4.9\end{array}$ & - & $\begin{array}{l}23 \cdot 7-26 \cdot 0 \\
15 \cdot 0-16 \cdot 2\end{array}$ \\
\hline \multicolumn{5}{|c|}{ White blood cells } \\
\hline protein & $2 \cdot 56$ & $3 \cdot 84$ & - & $3 \cdot 39$ \\
\hline \multicolumn{5}{|l|}{ GPI IU/mg } \\
\hline protein & - & 一 & 0.054 & $0 \cdot 23 *$ \\
\hline GPI/LDH & 一 & 一 & 0.084 & $0 \cdot 37^{*}$ \\
\hline $\begin{array}{l}\text { Thermal stability } \\
(\% \text { initial activity } \\
\text { after } 20 \text { mins at } 45^{\circ} \mathrm{C}\end{array}$ & & & & \\
\hline White blood cells & 90 & 65 & 一 & 90 \\
\hline Placenta & 一 & 一 & 57 & 98 \\
\hline \multicolumn{5}{|l|}{$K m F 6 P(m M)$} \\
\hline White blood cells & $0 \cdot 70$ & $0 \cdot 17$ & - & $0 \cdot 29$ \\
\hline Placenta & 一 & 一 & 0.40 & $0 \cdot 36$ \\
\hline \multicolumn{5}{|l|}{ pH optimum } \\
\hline White blood cells & $8 \cdot 6$ & $8 \cdot 6$ & 一 & $8 \cdot 6$ \\
\hline
\end{tabular}

*Controls were term placentae stored at $-20^{\circ} \mathrm{C}$ for the same duration as the test material in each case. 
Starch gel electrophoresis of the placenta showed a heat labile variant isozyme exactly comparable to that seen in the white cells of the mother. There was also a weak isozyme with the same electrophoretic mobility as GPI 1 and of normal heat stability (Fig. 3c).
These results show that the mother was hetero zygous for the common $G P I^{1}$ allele and a variant allele which determines a heat labile, electrophoretic $\vec{F}$ ally-distinct form of GPI. The father is probably alsof heterozygous for $G P I^{1}$ and a variant allele. However? in his case, the variant allele appears to determine

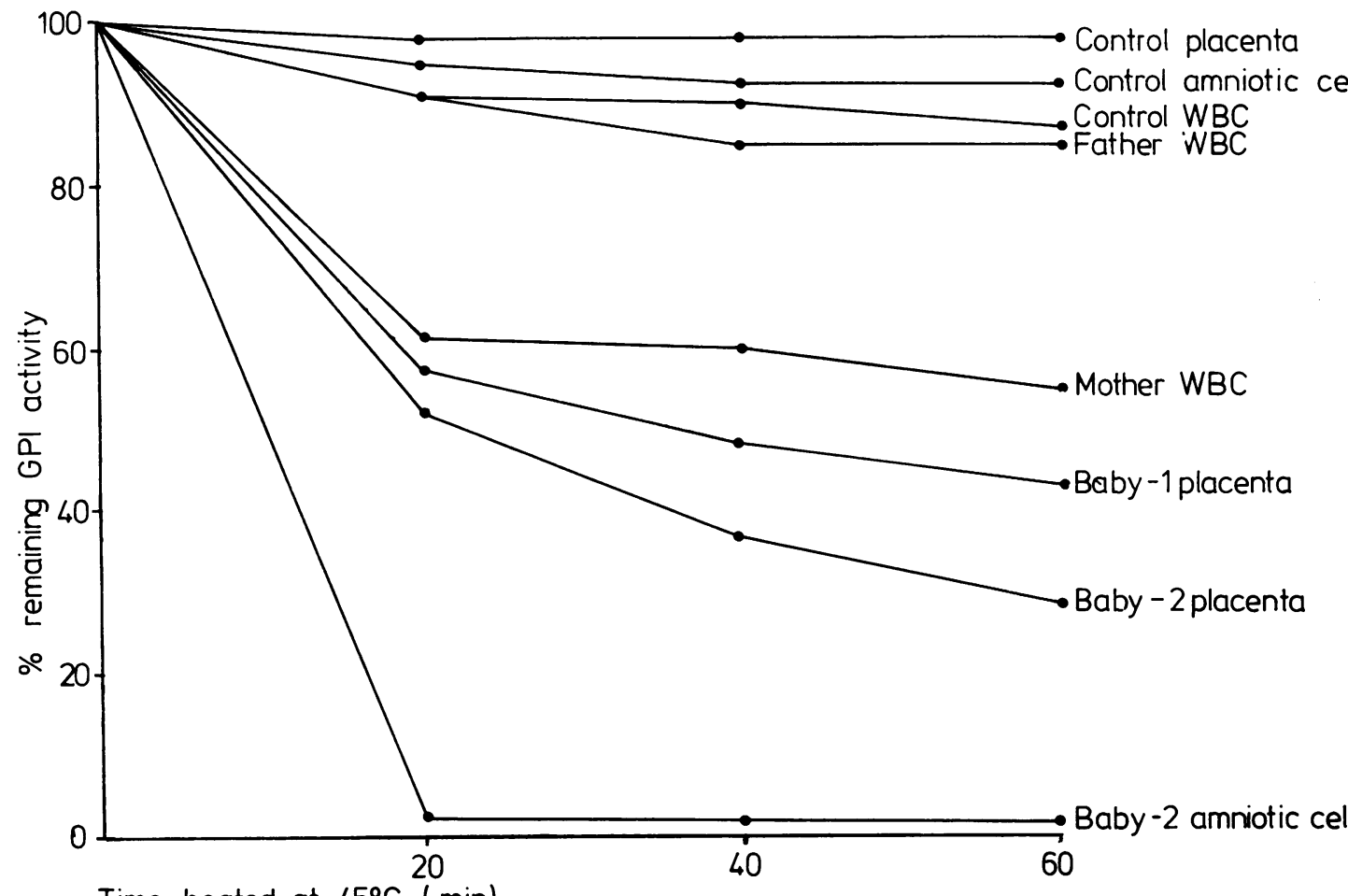

Time heated at $45^{\circ} \mathrm{C}(\mathrm{min})$

Fig. 2 Heat stability profiles of GPI in various tissues from the parents II.1 and II.2, and their offspring III.1 and III.2.
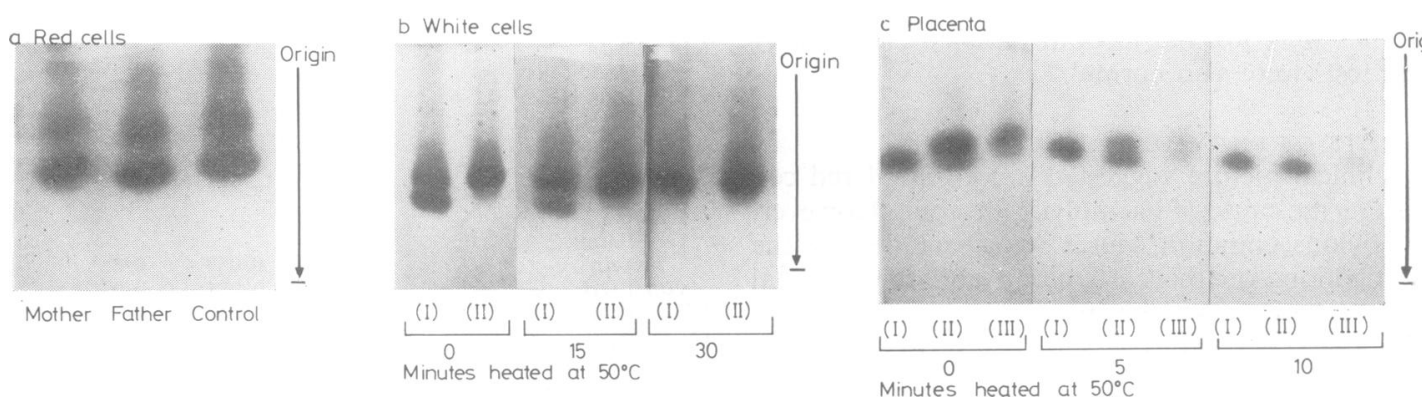

Fig. 3 Photographs of starch gels. (a) GPI isozymes in red cells from parents II.1 and II.2 compared with the GPI 1 control. Electrophoresis in Tris/citrate at pH 8.6. (b) GPI isozymes in white cells from (i) mother, (ii) GPI 1 control, after heating the isozymes in situ in the gel at $50^{\circ}$ for 0,15 , and 30 min. Electrophoresis in Tris/chloride at pH 8.6. (c) GPI isozymes in placentae from (i) control (extract diluted), (ii) case 1 (extract undiluted), and (iii) case 1 (extract diluted) after heating the isozymes in situ in the gel at $50^{\circ}$ for 0 , 5 , and 10 min. Electrophoresis in Tris/citrate at pH 8.6. 
form of GPI with low specific activity, which is indistinguishable by electrophoresis, heat stability, and kinetics from the common GPI 1 isozyme. The results obtained from the placenta of case 1 confirmed that this child inherited both parental variant GPI alleles.

\section{Case report: case 2}

\section{PREGNANCY}

The mother became pregnant again while the above investigations were being carried out. She remained normotensive throughout this pregnancy, did not work as a dental nurse, and rested more than in her first pregnancy. Since we had no previous experience of GPI assay in cultured cells from amniotic fluid and did not know what the prognosis for another affected child would be, it was agreed with the parents not to attempt early prenatal diagnosis with a view to termination if the fetus was thought to be affected. However, it was decided that it would be worth monitoring the last trimester and inducing early if the fetus appeared to be severely affected.

\section{AMNIOCENTESIS}

This was performed at 28 weeks. The liquor was stained and showed an optical density of 0.22 at $450 \mathrm{~nm}$, confirming a raised bilirubin level. Amnio fluid cells were cultured and the GPI was characterised (Table 2 ). The activity was about $37 \%$ of the mean of 4 controls and the enzyme was found to be heat labile. After heating, the cells retained only $1 \%$ of the initial GPI activity, compared with $94 \%$ in the control cells. Electrophoretic studies revealed an isozyme pattern identical to that seen in the placenta of the first baby. It was concluded that this second child was, like the first, heterozygous for the 2 different variant GPI alleles, and was at risk for haemolytic anaemia.

Table 2 GPI activity and properties of cultured amniotic fluid cells, red cells, and placenta from case 2 (III.2)

\begin{tabular}{|c|c|c|c|c|}
\hline Cells & $\begin{array}{l}\text { GPI } \\
\text { activity }\end{array}$ & $\begin{array}{l}G P I / L D H \\
\text { activity }\end{array}$ & $\begin{array}{l}\text { Thermal } \\
\text { stability (\% } \\
\text { initial activity } \\
\text { after } 20 \text { mins } \\
\left.\text { at } 45^{\circ} \mathrm{C}\right)\end{array}$ & $\begin{array}{l}K m F 6 P \\
(m M)\end{array}$ \\
\hline Amniotic cells & $0 \cdot 27$ & 一 & $1 \cdot 1$ & - \\
\hline $\begin{array}{l}\text { Controls mean } \\
\text { (IU/mg protein) }\end{array}$ & $0.73^{+}$ & - & 94 & 一 \\
\hline Red cells & $9 \cdot 15$ & $2 \cdot 8$ & - & - \\
\hline $\begin{array}{l}\text { Controls } \\
\text { (IU/g Hb) }\end{array}$ & $23 \cdot 7-26 \cdot 0$ & $15 \cdot 0-16 \cdot 2$ & - & - \\
\hline Placenta & 0.139 & 0.067 & 53 & 0.39 \\
\hline $\begin{array}{l}\text { Controls } \\
\text { (IU/mg protein) }\end{array}$ & $0.36^{*}$ & 0.22 & 98 & 0.36 \\
\hline
\end{tabular}

*Controls were term placentae stored at $-20^{\circ} \mathrm{C}$ for the same period as the test material in each case.

+Mean of four controls.

\section{CLINICAL FEATURES}

The labour started spontaneously at 35 weeks' gestation, but the fetus developed type II cardiac decelerations. A lower segment caesarian section was performed with delivery of a male infant of birthweight $2 \cdot 61 \mathrm{~kg}$ and head circumference $34 \mathrm{~cm}$. He was pale and had gross enlargement of the liver, but was not hydropic. At 1 minute he had an Apgar score of 4 . He was intubated at 2 minutes and given intermittent positive pressure ventilation with oxygen, with an immediate improvement in heart rate, and he breathed spontaneously at 4 minutes. He had regular adequate respirations by 9 minutes.

The cord blood haemoglobin was $6.8 \mathrm{~g} / \mathrm{dl}$, white cell count $12 \cdot 3 \times 10^{9} / 1$, normoblasts $78 / 100 \mathrm{wbc}$, and reticulocytes $80 \%$. The red cell morphology was identical to that seen in case 1 . Heinz bodies were not seen. Blood group was A Rhesus negative and the direct antiglobulin test was negative. The cord blood bilirubin was raised at $110 \mu \mathrm{mol} / \mathrm{l}$.

Exchange transfusion was carried out at 3 hours with $200 \mathrm{ml}$ A Rhesus negative packed red cells. The baby had rapid shallow respiration, but did not require high concentrations of oxygen. An $x$-ray showed cardiac enlargement and confirmed gross hepatic enlargement. Over the next 5 hours the abdomen became soft, the liver slightly smaller, and it became possible to feel an enlarged spleen.

Plasma unconjugated bilirubin rose to a maximum of $200 \mu \mathrm{mol} / \mathrm{l}$, but after the first 24 hours the bilirubin was predominantly conjugated. After exchange transfusion the baby's haemoglobin level rose to $11.5 \mathrm{~g} / \mathrm{dl}$ and the reticulocyte count fell to 2 to $3 \%$, but rose again to $29 \%$ at one month. His haemoglobin initially remained high, but at just over 1 week dropped again to $8 \mathrm{~g} / \mathrm{dl}$ and subsequently continued to fall slowly. Urine samples collected on the second and third day showed a relatively normal pattern of organic acid excretion, though gluconic and glucaric acid were somewhat raised.

He was discharged home at 1 month at a weight of $2.68 \mathrm{~kg}$ and a haemoglobin level of about $6 \mathrm{~g} / \mathrm{dl}$. He was feeding on his own satisfactorily. He was followed twice weekly thereafter. By $6 \frac{1}{2}$ weeks his haemoglobin had fallen further to $4.9 \mathrm{~g} / \mathrm{dl}$, despite iron, folate, and vitamin supplements. At this time he had begun to tire on feeding, so he was given a blood transfusion to a $\mathrm{Hb}$ level of $15 \mathrm{~g} / \mathrm{dl}$. By 11 weeks his $\mathrm{Hb}$ had again dropped to $5.4 \mathrm{~g} / \mathrm{dl}$ and he received a further transfusion. His growth and development are otherwise normal.

GPI ASSAYS

The results obtained on the cord blood and the placenta from case 2 confirmed the findings on the amniotic cells (Table 2). There was severe deficiency 
of GPI and the isozymes were indistinguishable by electrophoresis and heat stability from those seen in the placenta of case 1 , and in the amniotic cells from case 2.

\section{MERCURY ASSAYS}

Because the mother had worked as a dental nurse during her first pregnancy, it was suspected that she might have been exposed to mercury vapour from the amalgam used for tooth fillings. Such intoxication, if it occurred, might exacerbate the effects of GPI deficiency and contribute to the more severe degree of haemolysis seen in the first baby. Accordingly, placental samples from both pregnancies were kindly assayed for mercury by Professor D. G. Wibberley of the University of Aston. His reported findings are shown in Table 3.

\section{FAMILY STUDIES}

Results of GPI assays on red cells from various members of the family are given in Fig. 1. In addition to the parents, levels in the heterozygote range were observed in maternal sibs II.3 and II.4 and in one subject in the earlier generation I.3.

\section{Discussion}

The severity of non-spherocytic haemolytic anaemia has varied in reported cases of GPI deficiency. Most cases have been diagnosed during childhood and those patients who have had a splenectomy have shown reduced haemolysis and dependence on transfusion, with the sole exception of GPI Utrecht in which there is also a unique susceptibility to the effect of drugs and infections (Helleman and van Biervliet, 1976). Less common are the more severe cases which present with neonatal jaundice (Paglia et al., 1969; Miwa et al., 1973a, b), which may even require exchange transfusion, and in one case (Hutton and Chilcote, 1974) GPI deficiency has resulted in neonatal death. As far as we can ascertain, of the two affected sibs presented here, case 1 is the first instance in which haemolysis has been so severe as to result in hydrops fetalis.

In this family both parents appear to be heterozygous for a different GPI variant allele associated with deficiency of the enzyme. The variant allele, when in heterozygous combination with the common $\left(G P I^{1}\right)$ allele, does not result in any clinical abnormality. The sibs inherited both the variant parental alleles and were thus heterozygous for two different

Table 3 Placental mercury in $\mu \mathrm{g} / 100 \mathrm{~g}$ fresh weight

\begin{tabular}{ll}
\hline Sample & Mercury level \\
\hline Placenta of III.1 & 1.06 \\
Placenta of III.2 & 0.68 \\
Control of placenta (i) & 0.20 \\
Control placenta (ii) & 1.47 \\
\hline
\end{tabular}

deficient alleles. Double or compound heterozygosit such as this has been reported in other patients witht congenital GPI deficiency (Baughan et al., 1968 Detter et al., 1968; Blume et al., 1972; Engelhardt et al., 1973; Schröter et al., 1974; van Biervliet et al.둥 1975; Kahn et al., 1977). In this case, there was no parental consanguinity as has been seen in severaf families with apparent homozygosity of affecteo subjects (Paglia et al., 1969, 1975; Arnold et al.\$p 1973, 1977; Nakashima et al., 1973; Beutler et al. $\overrightarrow{0}$ 1974; Hutton and Chilcote, 1974; Kahn et al., 1978); Both sibs in this family were heterozygous carriers of the same two variant alleles at the GPI locus, and? it is difficult to be sure why the first child was relatively more severely affected than the secondOne possibility which has been explored is mercury intoxication of the mother during the first pregnancy $\dot{\vec{\delta}}_{\mathrm{o}}$ when she was working as a dental nurse. Theo presence of mercury could have exacerbated the severity of the haemolytic disorder in the first baby? However results obtained from placental mercury estimations (Table 3) suggest that this was not the case

The organic aciduria detected in the first affected child was probably secondary to this infant'\$్ moribund state at the time of birth. The relatively normal urinary organic pattern in the second chil excludes any abnormality characteristic of this disorder.

The maternal variant GPI showed norma Michaelis constant and pH optimum, but marke\& heat lability and altered electrophoretic mobility o $\overrightarrow{\vec{B}}$ starch gels in the buffer systems used. Since previously reported electrophoretic variants with abnormal heaP stability have not been examined in these two buffere systems, it is not possible to say whether they are identical with this particular heat labile varian (Hutton and Chilcote, 1974; Schröter et al., 1974 Paglia et al., 1975; Kahn et al., 1976, 1978). Thê. father's GPI showed normal Michaelis constant, $\mathrm{p} \Phi$ optimum, heat stability, and electrophoretic mobility? His low GPI activity was probably the result of 8 variant allele which determines a form of GPI with low specific activity, which is indistinguishable fror the usual GPI 1 isozyme by the tests used. Studiess are in progress to characterise further the paterna? variant enzyme.

Heterozygotes for a dimeric enzyme such as GP would usually be expected to show 3 major isozyme resulting from the random association of 2 sub-units The middle band (heterodimer) of the triplet woulf be the most intense and the 2 homodimers would b\& expected to be equally active. In the mother's white cells, 2 isozymes of approximately equal intensit? were seen, one with the same mobility as the commo GPI 1 isozyme. It seems likely that the latter isozyme has the sub-unit structure $\alpha^{1} \alpha^{1}$, where $\alpha^{1}$ is the 
product of the $G P I^{1}$ allele, and the variant isozyme corresponds to the heterodimer $\alpha^{1} \alpha^{\mathrm{M}}$, where $\alpha^{\mathrm{M}}$ is the product of the maternal variant allele. The absence of the variant homodimer $\alpha^{\mathbf{M}} \mathbf{M}^{\mathbf{M}}$ is probably the result of its being particularly unstable. An alternative, but less likely, explanation is that structural features of the variant $\left(\alpha^{M}\right)$ enzyme sub-units prevent their dimerisation with each other but not with the normal $\left(\alpha^{1}\right)$ sub-units. In red cells which cannot synthesise new protein, the effects of the instability are more pronounced so that only the normal homodimeric $\alpha^{1} \alpha^{1}$ was seen in the mother's red cells.

Two-banded isozyme patterns were also seen in the placentae of the sibs. One isozyme had normal mobility, but was very weak compared with the usual GPI 1 isozyme. It is proposed that this isozyme is the variant homodimer $\alpha^{\mathrm{P}} \alpha^{\mathrm{P}}$, where $\alpha^{\mathrm{P}}$ is the product of the paternal variant allele. The other isozyme, with mobility identical to the variant isozyme seen in the mother, is probably the variant heterodimer $\alpha^{M_{\alpha}}{ }^{\mathrm{P}}$. As was the case with the mother, the variant homodimer $\alpha^{\mathrm{M}} \alpha^{\mathrm{M}}$ was not seen. According to this interpretation, the variant isozymes seen in the mother and children are different in their subunit structures, $\alpha^{1} \alpha^{\mathbf{M}}$ and $\alpha^{\mathbf{M}_{\alpha} \mathbf{P}}$, respectively, but are both unstable since each contains the $\alpha^{\mathrm{M}}$ sub-unit.

The father exhibited a single GPI isozyme. It seems likely that this consists of three components $\alpha^{1} \alpha^{1}$, $\alpha^{1} \alpha^{\mathrm{P}}$, and $\alpha^{\mathrm{P}} \alpha^{\mathrm{P}}$, all with the same electrophoretic mobility.

The distinctive features of the variant forms of GPI in this family made it possible to predict the outcome of the second pregnancy. The 4 possible genotypes of the offspring and the distinctive biochemical characteristics of the GPI in each case are shown in Table 4.

Antenatal diagnosis of GPI deficiency early in pregnancy has not previously been reported for the obvious reason that, on the basis of cases reported so far, when properly treated it is only rarely fatal and has a good prognosis. The neonatal death of the first child in this family suggested that the outlook might be less favourable than usual and that antenatal diagnosis should be considered. Since we were uncertain of the prognosis for another affected child, it was decided not to attempt early antenatal diagnosis with a view to termination, but to do an amniocentesis in the third trimester. Thus, if the fetus appeared to be severely affected appropriate measures, such as early induction and exchange transfusion, could be undertaken. In the event, this turned out to be the right decision and the value of late antenatal diagnosis has been shown. It is proposed to increase the amount of blood administered at each transfusion in order to extend the time interval between transfusions without allowing the haemoglobin
Table 4 The 4 possible genotypes expected among the offspring of parents of the index case and their biochemical characteristics. There is an equal probability (1:4) for the occurrence of each genotype

\begin{tabular}{|c|c|c|c|c|}
\hline \multirow[t]{2}{*}{ Genotype } & \multirow[t]{2}{*}{ Phenotype } & \multicolumn{3}{|c|}{ Characteristics of GPI } \\
\hline & & $\begin{array}{l}\text { Activity } \\
\text { (expressed } \\
\text { as \% of } \\
\text { control) }\end{array}$ & $\begin{array}{l}\text { Heat } \\
\text { stability } \\
\text { (expressed } \\
\text { as } \% \text { of } \\
\text { control after } \\
\text { heating at } \\
45^{\circ} \mathrm{C} \text { for } 20 \\
\text { mins) }\end{array}$ & $\begin{array}{l}\text { Isozymes } \\
\text { (after starch } \\
\text { gel electro- } \\
\text { phoresis) }\end{array}$ \\
\hline$G P I^{1} G P I^{1}$ & Normal & $\begin{array}{l}\text { normal } \\
(100 \%)\end{array}$ & $\begin{array}{l}\text { stable } \\
(100 \%)\end{array}$ & $\begin{array}{l}\text { normal } \\
\text { (GPI 1) }\end{array}$ \\
\hline$G P I^{1} G P I \mathrm{M}$ & Heterozygote & $\begin{array}{l}\text { low } \\
(\simeq 50 \%)\end{array}$ & $\begin{array}{l}\text { unstable } \\
(\simeq 60 \%)\end{array}$ & $\begin{array}{l}\text { normal } \\
\text { (GPI 1) + } \\
\text { variant } \\
\text { (GPIM) }\end{array}$ \\
\hline$G P I^{1} G P I P$ & Heterozygote & $\begin{array}{l}\text { low } \\
(\simeq 50 \%)\end{array}$ & $\begin{array}{l}\text { stable } \\
(\simeq 100 \%)\end{array}$ & $\begin{array}{l}\text { 'normal' } \\
\text { (GPI1 + } \\
\text { GPIP) }\end{array}$ \\
\hline$G P I \mathrm{M} G P I \mathrm{P}$ & $\begin{array}{l}\text { Double } \\
\text { heterozygote }\end{array}$ & $\begin{array}{l}\text { very low } \\
(<40 \%)\end{array}$ & $\begin{array}{l}\text { unstable } \\
\text { ( } 60 \% \text { or less) }\end{array}$ & $\begin{array}{l}\text { variant } \\
(\text { GPIM) } \\
\text { 'normal' } \\
(\text { GPIP) }\end{array}$ \\
\hline
\end{tabular}

$G P I^{1}$ represents the common allele; GPIM represents the maternal variant allele which determines a heat labile electrophoretically distinct form of GPI; GPIP represents the paternal variant allele which determines a GPI with low specific activity which is indistinguishable by heat stability and electrophoresis from GPI'.

concentration to fall below a level that will permit normal growth and development. Hopefully, after splenectomy long term transfusion will not be necessary.

It is of interest that though GPI studies on the amniotic cells showed the second child to be affected, this was also strongly suggested by the yellow colour of the amniotic fluid as it was withdrawn and the confirmation that this was because of raised bilirubin. The above procedure is to be recommended in the management of pregnancy where there is a risk of a child with GPI deficiency. Until the frequency of GPI deficiency as a cause of hydrops fetalis has been determined, it ought to be looked for in all cases of unexplained hydrops fetalis with severe haemolysis.

Financial support from the Birth Defects Fund, University College Hospital Medical School for one of the authors (PAR) is gratefully acknowledged. We are also grateful to $\operatorname{Dr} M$. M. Liberman, the paediatrician caring for the two children, for his permission to report the clinical findings and to Dr R. Chalmers for the urine organic acid analyses.

\section{References}

Arnold, H., Blume, K. G., Engelhardt, R., and Löhr, G. W. (1973). Glucose phosphate isomerase deficiency: evidence for in vivo instability of an enzyme variant with hemolysis. Blood, 41, 691-699.

Arnold, H., Dodinal-Versie, J., Lambotte, C., Löhr, G. W., and Van Der Hofstedt, J. (1977). Glucose phosphate isomerase deficiency type Liege-new variant with 
congenital nonspherocytic hemolytic anemia. Blut, 35, 187-194.

Baughan, M. A., Valentine, W. N., Paglia, D. E., Ways, P. O., Simons, E. R., and DeMarsh, Q. B. (1968). Hereditary hemolytic anemia associated with glucose phosphate isomerase (GPI) deficiency-a new enzyme defect of human erythrocytes. Blood, 32, 236-249.

Beutler, E., Blume, K. G., Kaplan, J. C., Löhr, G. W., Ramot, B., and Valentine, W. N. (1977). International committee for standardization in haematology: recommended methods for red-cell enzyme analysis. British Journal of Haematology, 35, 331-340.

Beutler, E., Sigalove, W. H., Muir, W. A., Matsumoto, F., and West, C. (1974). Glucosephosphate-isomerase (GPI) deficiency: GPI Elyria. Annals of Internal Medicine, 80, 730-732.

Blake, N. M., Kirk, R. L., McDermid, E. M., Omoto, K., and Ahuja, Y. R. (1971). The distribution of serum protein and enzyme group systems among North Indians. Human Heredity, 21, 440-457.

Blume, K. G., Hryniuk, W., Powars, D., Trinidad, F., West, C., and Beutler, E. (1972). Characterization of two new variants of glucose phosphate isomerase deficiency with hereditary nonspherocytic hemolytic anemia. Journal of Laboratory and Clinical Medicine, 79, 942-949.

Chapman, R. G., Hennessey, M. A., Waltersdorph, A. M., Huennekens, F. M., and Gabrio, B. W. (1962). Erythrocyte metabolism. V. Levels of glycolytic enzymes and regulation of glycolysis. Journal of Clinical Investigation, 42, 12491256.

Detter, J. C., Ways, P. O., Giblett, E. R., Baughan, M. A., Hopkinson, D. A., Povey, S., and Harris, H. (1968). Inherited variations in human phosphohexose isomerase. Annals of Human Genetics, 31, 329-338.

Engelhardt, R., Arnold, H., Hoffmann, A., Jacobi, H., and Löhr, G. W. (1973). GPI-Recklinghausen: a variant of glucosephosphate isomerase deficiency with hemolytic anemia. In Erythrocytes, Thrombocytes, Leucocytes. Recent Advances in Membrane and Metabolic Research, pp. 180-182. Ed. by E. Garlach, K. Moser, and E. Deutsch. Thieme, Stuttgart.

Helleman, P. W., and van Biervliet, J. P. G. M. (1976). Haematological studies in a new variant of glucose phosphate isomerase deficiency (GPI Utrecht). Helvetica Paediatrica Acta, 30, 525-536.

Hutton, J. J., and Chilcote, R. R. (1974). Glucosephosphate isomerase deficiency with hereditary nonspherocytic hemolytic anemia. Journal of Pediatrics, 85, 494-497.

Kahn, A., Buc, H.-A., Girot, R., Cottreau, D., and Griscelli, C. (1978). Molecular and functional anomalies in two new mutant glucose phosphate isomerase variants with enzyme deficiency and chronic hemolysis. Human Genetics, 40, 293-304.

Kahn, A., Marie, J., Bertrand, J.-F., Cottreau, D., and Boivin, P. (1976). Mechanisms of the acquired erythrocyte enzyme deficiencies in blood diseases. Clinica Chimica Acta, 71, 379-387.

Kahn, A., van Biervliet, J. P. G. M., Vives-Corrons, J. L., Cottreau, D., and Staal, G. E. J. (1977). Genetic and molecular mechanisms of the congenital defects in glucose phosphate isomerase activity: studies of four families. Pediatric Research, 11, 1123-1129.

Keitt, A. S. (1971). Reduced nicotinamide adenine dinucleotide-linked analysis of 2,3-diphosphoglyceric acid: spectrophotometric and fluorimetric procedures. Journal of Laboratory and Clinical Medicine, 77, 470-475.

McAlpine, P. J., Hopkinson, D. A., and Harris, H. (1970). Thermostability studies on the isozymes of human phosphoglucomutase. Annals of Human Genetics, 34, 61-67.
McMorris, F. A., Chen, T. R., Ricciuti, F., Tischfield, J. Creagan, R., and Ruddle, F. H. (1973). Chromosome assignments in man of the genes for two hexosephosphate isomerase. Science, 179, 1129-1131.

Miwa, S., Nakashima, K., Oda, S., Matsumoto, N., Ogawa H., and Fukumoto, Y. (1973a). Glucosephosphate isomerase (GPI) deficiency hereditary nonspherocytic hemo $-\overline{\bar{G}}$ lytic anemia. Report of the first case found in Japanese $\bar{c}$ Acta Haematologica Japonica, 36, 65-69.

Miwa, S., Nakashima, K., Oda, S., Matsumoto, N., Ogawa H., Kobayashi, R., Kotani, M., Harata, A., Onaya, T.s్ and Yamada, T. (1973b). Glucosephosphate isomerase(GPI) deficiency hereditary nonspherocytic hemolytic anemia. Report of the second case found in Japanese $\overrightarrow{\vec{\omega}}$ Acta Haematologica Japonica, 36, 70-73.

Nakashima, K., Miwa, S., Oda, S., Oda, E., Matsumoto, N.S Fukumoto, Y., and Yamada, T. (1973). Electrophoretic and kinetic studies of glucosephosphate isomerase (GPI) in two different Japanese families with GPI deficiency. $\vec{\sigma}$ American Journal of Human Genetics, 25, 294-301.

$\omega$

Omoto, K., and Blake, N. M. (1972). Distribution of geneticvariants of erythrocyte phosphoglycerate kinase (PGK) and phosphohexose isomerase (PHI) among some popula-o tion groups in south-east Asia and Oceania. Annals of Human Genetics, 36, 61-67.

Paglia, D. E., Holland, P., Baughan, M. A., and Valentine,, W. M. (1969). Occurrence of defective hexosephosphate isomerization in human erythrocytes and leukocytes. New England Journal of Medicine, 280, 66-71.

Paglia, D. E., Paredes, R., Valentine, W. N., Dorantes, S. and Konrad, P. N. (1975). Unique phenotypic expression. of glucose phosphate isomerase deficiency. American Journal of Human Genetics, 27, 62-70.

Paglia, D. E., and Valentine, W. N. (1974). Hereditary glucose phosphate isomerase deficiency. A review. American Journal of Clinical Pathology, 62, 740-751.

Schröter, W., Koch, H. H., Wonneberger, B., Kalinowsky, W., Arnold, A., Blume, K. G., and Hüther, W. (1974). $\stackrel{\vec{F}}{\vec{D}}$ Glucose phosphate isomerase deficiency with congenitalo nonspherocytic hemolytic anemia: a new variant (type Nordhorn). I. Clinical and genetic studies. Pediatric Research, 8, 18-25.

Schröter, W., and Tillmann, W. (1977). Decreased deform ability of erythrocytes in haemolytic anaemia associated $\overline{3}$ with glucosephosphate isomerase deficiency. British Journal of Haematology, 36, 475-484.

Shinoda, T. (1970). Inherited variations in red cell phospho glucose isomerase among Japanese. Japanese Journal of Human Genetics, 15, 159-165.

Tariverdian, G., Arnold, H., Blume, K. G., Lenkeit, U., and Löhr, G. W. (1970). Zur formalgenetik der phospho-윽 glucoseisomerase (E.C. 5.3.1.9). Untersuchung einer sippe mit PGI-defizienz. Humangenetik, 10, 218-223.

van Biervliet, J. P. G. M. (1975). Glucose phosphate isomerase deficiency in a Dutch family. Acta Paediatrica $N$ Scandinavica, 64, 868-872.

van Biervliet, J. P., Vlug, A., Bartstra, H., Rotteveel, J. J., N de Vaan, G. A. M., and Staal, G. E. J. (1975). A newN variant of glucose phosphate isomerase deficiency. Humangenetik, 30, 35-40.

Welch, S. G. (1971). Qualitative and quantitative variants ofo human phosphoglucose isomerase. Human Heredity, 21, 467-477.

Requests for reprints to Dr D. A. Hopkinson, MRCo Human Biochemical Genetics Unit, The Galton Laboratory, University College London, Wolfson House, 4 Stephenson Way, London NW1 2HE. 